\title{
HUBUNGAN PRAKTIK PENCEGAHAN DAN KONDISI FISIK RUMAH PENDERITA TB PARU DENGAN KEJADIAN TB PARU DI WILAYAH KERJA PUSKESMAS II SUMPIUH KABUPATEN BANYUMAS TAHUN 2016
}

\author{
Umi Mukarromah ${ }^{1)}$, Lagiono ${ }^{2)}$, Budi Triyantoro ${ }^{3)}$ \\ Jurusan Kesehatan Lingkungan, Politeknik Kesehatan Kemenkes Semarang, \\ Jl.Raya Baturaden KM 12 Purwokerto, Indonesia
}

\begin{abstract}
Abstrak
Tuberkulosis (TB) Paru sampai saat ini masih merupakan masalah kesehatan, terutama di negara-negara berkembang termasuk Indonesia. Penelitian ini bertujuan untuk mengetahui hubungan praktik pencegahan dan kondisi fisik rumah dengan kejadian TB Paru di Wilayah Kerja Puskesmas II Sumpiuh Kabupaten Banyumas Tahun 2016. Penelitian ini dilakukan di Wilayah Kerja Puskesmas II Sumpiuh Kabupaten Banyumas pada bulan Maret - April tahun 2016 menggunakan rancangan penelitian case control dengan pendekatan retrospektif. Sampel dalam penelitian ini sebanyak 23 orang diambil dengan teknik total sampling dan sampel kontrol 46 orang diambil dengan teknik purposive sampling. Analisis data menggunakan uji Chi Square. Hasil penelitian ini menyatakan bahwa praktek pencegahan TB paru sebagian besar baik $=51$ orang $(73,9 \%)$, jenis lantai rumah memenuhi syarat $=43$ rumah $(62,3 \%)$, kondisi dinding rumah memenuhi syarat $=55$ rumah $(79,7 \%)$, ventilasi rumah memenuhi syarat $=46$ rumah $(66,7 \%)$, kondisi dapur rumah memenuhi syarat $=55$ rumah $(79,7 \%)$ dan kepadatan hunian memenuhi syarat $=61$ rumah $(88,4 \%)$. Ada hubungan antara praktik pencegahan TB paru ( $p$ value $=0,020 ; O R=3,654)$, jenis lantai ( $p$ value $=0,022 ;$ OR = $3,300)$, dinding rumah ( $p$ value $=0,001 ; O R=6,395)$, ventilasi rumah $(p$ value $=0,019 ; O R=3,471)$, kondisi fisik dapur ( $p$ value $=0,006 ; O R=5,271)$ dan kepadatan hunian rumah ( $p$ value $=0,001 ; O R=19,688)$. dengan kejadian TB Paru di Wilayah Kerja Puskesmas II Sumpiuh Kabupaten Banyumas. Kesimpulan penelitian ini yaitu ada hubungan hubungan praktik pencegahan dan kondisi fisik rumah dengan kejadian TB Paru di Wilayah Kerja Puskesmas II Sumpiuh Kabupaten Banyumas Tahun 2016. Hasil penelitian ini perlu dipublikasikan sebagai bahan referensi ilmiah dan kepustakaan sekaligus sebagai bahan pengembangan ilmu kesehatan khususnya penanggulangan penyakit TB paru di masyarakat melalui perubahan perilaku dan perbaikan lingkungan.
\end{abstract}

Kata Kunci : TB Paru, Rumah

\begin{abstract}
Tuberculosis (TB) Lung's is still a health problem, especially in developing countries, including Indonesia. This study aims to determine the relationship of prevention practices and the physical condition and the incidence of pulmonary TB in Puskesmas II Sumpiuh Banyumas 2016. This research was conducted in Puskesmas II Sumpiuh Banyumas on March-April 2016 use case control study design with a retrospective approach. Sample in this research are 23 people were taken with total sampling and control sample 46 people taken by purposive sampling technique. Data analysis in this research use Chi Square test. The results of this study stated that the practice of pulmonary tuberculosis prevention is mostly good $=51(73.9 \%)$, the type of floor house qualifies = 43 homes $(62.3 \%)$, the condition of the walls of the house are eligible $=55$ homes $(79.7 \%)$, ventilation home qualifies $=46$ homes $(66.7 \%)$, the condition of a home kitchen eligible $=55$ homes $(79.7 \%)$ and residential density qualify $=61$ houses $(88.4 \%)$. There is a relationship between the practice of prevention of pulmonary tuberculosis ( $p$ value $=0.020 ; \mathrm{OR}=3.654)$, type of flooring ( $p$ value $=0.022 ; \mathrm{OR}$ $=3.300)$, the walls of the house ( $p$ value $=0.001 ; O R=6.395)$, home ventilation $(p$ value $=0.019 ; O R=3.471)$, the physical condition of kitchens ( $p$ value $=0.006 ;$ OR $=5.271$ ) and density of dwelling ( $p$ value $=0.001$; OR $=19.688$ ). the incidence of pulmonary TB in Puskesmas II Sumpiuh Banyumas. The conclusion from this study is there is a relationship between the practice prevention and conditions home of TB patient with TB pulmonary events in Puskesmas II Sumpiuh Banyumas Year 2016. The results of this research should be published as a scientific reference material and literature as well as material development of health sciences, especially pulmonary tuberculosis disease prevention in the community through behavior change and environmental improvement.
\end{abstract}

Keywords : Tuberculosis (TB) Lung, House

\section{PENDAHULUAN}

Tuberkulosis (TB) Paru sampai saat ini masih merupakan masalah kesehatan, terutama di negara-negara berkembang termasuk Indonesia. Menurut World Health Organization (WHO), Indonesia sampai dengan tahun 2014 menempati urutan kedua dari 5 negara terbesar di dunia

\footnotetext{
1) E-mail: mukarromah@gmail.com

2) E-mail: lagionoabdulwahid@yahoo.co.id

3)E-mail: mutshabira@yahoo.co.id
} 
sebagai penyumbang penderita TB terbanyak setelah negara India, China, Nigeria dan Pakistan. Berdasarkan WHO Global Report 2014, angka Insidens TB tahun 2014 adalah 183/100.000 penduduk, sedangkan angka prevalensi TB adalah 272/100.000 penduduk dan angka mortalitas TB adalah 25/100.000 penduduk. Pada tahun 2014 (Kemenkes RI, 2015).

Penemuan kasus dan tingkat kesembuhan TB secara nasional menunjukkan perkembangan yang meningkat, meskipun pencapaian di tingkat provinsi masih menunjukkan disparitas antar wilayah. Sebanyak 28 provinsi di Indonesia belum dapat mencapai angka penemuan kasus (Case Detection Rate/CDR) $70 \%$ dan hanya 5 provinsi menunjukkan pencapaian 70\% CDR dan 85\% kesembuhan (Papua Barat, Papua, DIY, Malut, Riau) (Kemenkes RI, 2011).

Proporsi BTA positif kasus TB Paru pada tahun 2012 tertinggi di Provinsi Sulawesi Tenggara (94\%), Sulawesi Utara dan Jambi masing-masing 92\%, sedangkan capaian terendah yaitu Provinsi Papua Barat (31\%), DKI Jakarta (33\%) dan Papua (38\%). Sebanyak 21 dari 33 provinsi (63,6\%) telah mencapai target minimal 65\% (Kemenkes RI, 2013).

Angka penemuan kasus baru TB Paru di Provinsi Jawa Tengah Tahun 2013 baru mencapai 58,48\%. Angka kesembuhan (Cure Rate/CR) TB paru Provinsi Jawa Tengah tahun 2012 sebesar 82,90\% dibawah target nasional (85\%) dan lebih sedikit bila dibandingkan tahun 2011 (85,15\%) (Profil Kesehatan Provinsi Jawa Tengah, 2013). Jumlah suspek TB paru di Kabupaten Banyumas Tahun 2014 sebanyak 1.454 kasus dan terdiagnosis BTA + sebanyak 1.991 kasus yang lebih banyak dibandingkan jumlah suspek (Dinkes Kabupaten Banyumas, 2014)

Jumlah perkiraan kasus baru di Puskesmas Sumpiuh pada tahun 2014 sebesar 48,7 \% dengan sebanyak 39 kasus dan ditemukan 19 kasus (Dinkes Kabupaten Banyumas, 2014). Hal tersebut menunjukkan upaya penanggulangan TB paru, khususnya di Puskesmas Sumpiuh masih sangat diperlukan.
Strategi program penanggulangan TB paru yang digunakan di Indonesia adalah strategi Directly Observed Treatment Shortcourse (DOTS). Penemuan penderita TB Paru dalam strategi ini dilakukan secara pasif (passive case finding) yaitu penjaringan suspek TB paru dilaksanakan hanya pada penderita yang berkunjung ke sarana pelayanan kesehatan. WHO merekomendasikan strategi DOTS sebagai strategi dalam pengendalian TB paru sejak tahun 1995 (Kemenkes RI, 2013).

Evaluasi pengobatan pada penderita TB paru BTA (+) dilakukan melalui pemeriksaan dahak mikroskopis pada akhir fase intensif satu bulan sebelum akhir pengobatan dan pada akhir pengobatan dengan hasil pemeriksaan negatif. Dinyatakan sembuh bila hasil pemeriksaan dahak pada akhir pengobatan ditambah minimal satu kali pemeriksaan sebelumnya (sesudah fase awal atau satu bulan sebelum akhir pengobatan) hasilnya negatif (Dinkes Jateng, 2013).

Bertitik tolak dari masih adanya kasus TB paru, mendorong peneliti untuk melakukan penelitian dengan mengambil judul "Hubungan praktik pencegahan dan kondisi fisik rumah dengan kejadian TB Paru di Wilayah Kerja Puskesmas II Sumpiuh Kabupaten Banyumas Tahun 2016”.

Penelitian ini bertujuan untuk Mengetahui hubungan praktik pencegahan dan kondisi fisik rumah dengan kejadian TB Paru di Wilayah Kerja Puskesmas II Sumpiuh Kabupaten Banyumas Tahun 2016.

\section{METODE PENELITIAN}

Penelitian ini dilakukan di Wilayah Kerja Puskesmas II Sumpiuh Kabupaten Banyumas pada bulan Maret - April tahun 2016 menggunakan rancangan penelitian case control dengan pendekatan retrospektif. Sampel dalam penelitian ini sebanyak 23 orang diambil dengan teknik total sampling dan sampel kontrol 46 orang diambil dengan teknik purposive sampling. Analisis data menggunakan uji Chi Square. 


\section{HASIL PENELITIAN DAN}

\section{PEMBAHASAN}

\section{A. Hasil Analisis Univariat}

Analisis univariat adalah analisis yang dilakukan untuk mendeskripsikan setiap variabel yang diteliti yang meliputi praktik pencegahan, kondisi fisik rumah penderita TB Paru dan kejadian TB paru, yang hasilnya disajikan pada tabel 4.1 berikut ini.

1. Praktik Pencegahan TB Paru

Praktik pencegahan TB Paru di Wilayah Kerja Puskesmas II Sumpiuh Kabupaten Banyumas disajikan pada tabel 1.

\section{TABEL 1. DISTRIBUSI}

FREKUENSI PRAKTIK

PENCEGAHAN TB PARU DI

WILAYAH KERJA PUSKESMAS II

SUMPIUH KABUPATEN

BANYUMAS $(\mathrm{N}=69)$

\begin{tabular}{lll}
\hline $\begin{array}{l}\text { Praktik } \\
\begin{array}{l}\text { Pencegahan } \\
\text { TB Paru }\end{array}\end{array}$ & $\begin{array}{l}\text { Frekuen } \\
\text { si }\end{array}$ & $\%$ \\
\hline $\begin{array}{l}\text { Tidak } \\
\text { memenuhi } \\
\text { syarat/Tidak }\end{array}$ & 18 & 26,1 \\
$\begin{array}{l}\text { Baik } \\
\text { Memenuhi } \\
\text { syarat/Baik }\end{array}$ & 51 & 73,9 \\
\hline Jumlah & 69 & 100,0 \\
\hline
\end{tabular}

Responden yang diteliti sebanyak 69 orang, yang praktik pencegahan TB paru tidak baik sebanyak 18 orang $(26,1 \%)$ dan yang baik sebanyak 51 orang (73,9\%).

2. Jenis lantai rumah

Jenis lantai rumah responden di Wilayah Kerja Puskesmas II Sumpiuh Kabupaten Banyumas disajikan pada tabel 2.

TABEL 2. DISTRIBUSI

FREKUENSI JENIS LANTAI

RUMAH DI WILAYAH KERJA

PUSKESMAS II SUMPIUH
KABUPATEN BANYUMAS ( $\mathrm{N}=$ 69)

\begin{tabular}{lll}
\hline $\begin{array}{l}\text { Jenis lantai } \\
\text { rumah }\end{array}$ & Frekuensi & $\%$ \\
\hline $\begin{array}{l}\text { Tidak } \\
\text { memenuhi } \\
\text { syarat/Tidak }\end{array}$ & 26 & 37,7 \\
$\begin{array}{l}\text { Baik } \\
\text { Memenuhi } \\
\text { syarat/Baik }\end{array}$ & 43 & 62,3 \\
\hline Jumlah & 69 & 100,0 \\
\hline
\end{tabular}

Responden yang diteliti sebanyak 69 rumah, yang jenis lantai rumah tidak memenuhi syarat sebanyak 26 rumah (37,7\%) dan yang memenuhi syarat sebanyak 43 rumah (62,3\%).

3. Kondisi dinding rumah Kondisi dinding rumah responden di Wilayah Kerja Puskesmas II Sumpiuh Kabupaten Banyumas disajikan pada tabel 3.

TABEL 3. DISTRIBUSI

FREKUENSI KONDISI DINDING RUMAH DI WILAYAH KERJA PUSKESMAS II SUMPIUH KABUPATEN BANYUMAS $(\mathrm{N}=$ 69)

\begin{tabular}{|c|c|c|}
\hline $\begin{array}{l}\text { Kondisi } \\
\text { dinding rumah }\end{array}$ & Frekuensi & $\%$ \\
\hline $\begin{array}{l}\text { Tidak } \\
\text { memenuhi } \\
\text { syarat/Tidak } \\
\text { Baik }\end{array}$ & 14 & 20,3 \\
\hline $\begin{array}{l}\text { Memenuhi } \\
\text { syarat/Baik }\end{array}$ & 55 & 79,7 \\
\hline Jumlah & 69 & 79,7 \\
\hline \multicolumn{3}{|c|}{$\begin{array}{l}\text { Responden yang diteliti } \\
\text { sebanyak } 69 \text { rumah, yang kondisi } \\
\text { dinding rumah tidak memenuhi syarat } \\
\text { sebanyak } 14 \text { rumah }(20,3 \%) \text { dan yang } \\
\text { memenuhi syarat sebanyak } 55 \text { rumah } \\
(79,7 \%) \text {. }\end{array}$} \\
\hline
\end{tabular}

4. Ventilasi udara rumah 
$\begin{array}{llcr}\text { Ventilasi } & \text { udara } & \text { rumah } \\ \text { responden di } & \text { Wilayah } & \text { Kerja }\end{array}$

Puskesmas II Sumpiuh Kabupaten

Banyumas disajikan pada tabel 4.

Tabel 4. DISTRIBUSI FREKUENSI

VENTILASI UDARA RUMAH DI

WILAYAH KERJA PUSKESMAS

II SUMPIUH KABUPATEN

BANYUMAS $(\mathrm{N}=69)$

\begin{tabular}{lll}
\hline $\begin{array}{l}\text { Ventilasi } \\
\text { udara rumah }\end{array}$ & Frekuensi & $\%$ \\
\hline $\begin{array}{l}\text { Tidak } \\
\text { memenuhi }\end{array}$ & 23 & 33,3 \\
$\begin{array}{l}\text { syarat/Tidak } \\
\text { Baik }\end{array}$ & & \\
$\begin{array}{l}\text { Memenuhi } \\
\text { syarat/Baik }\end{array}$ & 46 & 66,7 \\
\hline Jumlah & 69 & 100,0 \\
\hline
\end{tabular}

Responden yang diteliti sebanyak 69 rumah, yang ventilasi rumah tidak memenuhi syarat sebanyak 23 rumah (33,3\%) dan yang memenuhi syarat sebanyak 46 rumah $(66,7 \%)$.

5. Kondisi dapur
Kondisi
responden di Wilayah Kerja
Puskesmas II Sumpiuh Kabupaten
Banyumas disajikan pada tabel 5.

TABEL 5. DISTRIBUSI FREKUENSI KONDISI DAPUR RUMAH DI WILAYAH KERJA PUSKESMAS II SUMPIUH KABUPATEN BANYUMAS $(\mathrm{N}=$ 69)

\begin{tabular}{lll}
\hline $\begin{array}{l}\text { Kondisi } \\
\text { dapur }\end{array}$ & Frekuensi & $\%$ \\
\hline $\begin{array}{l}\text { Tidak } \\
\text { memenuhi }\end{array}$ & 14 & 20,3 \\
$\begin{array}{l}\text { syarat/Tidak } \\
\text { Baik }\end{array}$ & & \\
$\begin{array}{l}\text { Memenuhi } \\
\text { syarat/Baik }\end{array}$ & 55 & 79,7 \\
\hline Jumlah & 69 & 100,0 \\
\hline
\end{tabular}

Responden yang diteliti sebanyak 69 rumah, yang kondisi dapur rumah tidak memenuhi syarat sebanyak 14 rumah (20,3\%) dan yang memenuhi syarat sebanyak 55 rumah (79,7\%).

6. Kepadatan rumah

Kepadatan rumah responden di Wilayah Kerja Puskesmas II Sumpiuh Kabupaten Banyumas disajikan pada tabel 6 .

\section{TABEL 6. DISTRIBUSI FREKUENSI KEPADATAN HUNIAN RUMAH DI WILAYAH KERJA PUSKESMAS II SUMPIUH KABUPATEN BANYUMAS $(\mathrm{N}=$ 69)}

\begin{tabular}{lll} 
Kepadatan rumah & Frekuensi & $\%$ \\
\hline $\begin{array}{l}\text { Tidak memenuhi } \\
\text { syarat/Tidak }\end{array}$ & 8 & 11,6 \\
$\begin{array}{l}\text { Baik } \\
\text { Memenuhi } \\
\text { syarat/Baik }\end{array}$ & 61 & 88,4 \\
\hline Jumlah & 69 & 100,0 \\
\hline
\end{tabular}

Responden yang diteliti sebanyak 69 rumah, yang kepadatan hunian tidak memenuhi syarat sebanyak 8 rumah $(11,6 \%)$ dan yang memenuhi syarat sebanyak 61 rumah (88,4\%).

7. Kejadian TB Paru

Kejadian TB Paru di Wilayah Kerja Puskesmas II Sumpiuh Kabupaten Banyumas disajikan pada tabel 7.

TABEL 7 DISTRIBUSI FREKUENSI

KEJADIAN TB PARU

DI WILAYAH KERJA

PUSKESMAS II

SUMPIUH

KABUPATEN

BANYUMAS $(\mathrm{N}=69)$

\begin{tabular}{lll} 
Kejadian TB Paru & Frekuensi & $\%$ \\
\hline Kasus & 23 & 33,3 \\
Kontrol & 46 & 66,7 \\
\hline
\end{tabular}


Jumlah

$$
69
$$

100,0

Responden yang diteliti sebanyak 69 orang, diketahui sebanyak 23 orang menderita TB paru $(33,3 \%)$ dan yang kontrol menderita TB paru sebanyak 46 orang (66,7\%).

\section{B. Hasil Analisis Bivariat}

Analisis bivariat dilakukan untuk mengetahui hubungan praktik pencegahan TB paru dan kondisi fisik rumah penderita TB Paru dengan Kejadian TB Paru. Hasil analisis bivariat menggunakan uji Chi Square hasilnya disajikan berikut ini.

1. Hubungan praktik pencegahan TB Paru dengan kejadian TB Paru di Wilayah Kerja Puskesmas II Sumpiuh Kabupaten Banyumas

Analisis hubungan praktik pencegahan TB Paru dengan kejadian TB Paru di Wilayah Kerja Puskesmas II Sumpiuh Kabupaten Banyumas menggunakan uji Chi Square yang hasilnya disajikan pada tabel berikut ini.

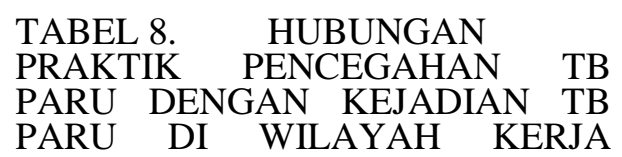

PUSKESMAS II SUMPIUH KABUPATEN BANYUMAS

\begin{tabular}{|c|c|c|c|c|c|c|c|}
\hline \multirow{3}{*}{$\begin{array}{l}\text { Praktik } \\
\text { Pencegahan } \\
\text { TB Paru }\end{array}$} & \multicolumn{4}{|c|}{ Kejadian TB Paru } & \multirow{3}{*}{$p$} & \multirow{3}{*}{ OR } & \multirow{3}{*}{ CI95\% } \\
\hline & \multicolumn{2}{|c|}{ Ya } & \multicolumn{2}{|c|}{ Tidak } & & & \\
\hline & $\mathrm{n}$ & $\%$ & $\mathrm{n}$ & $\%$ & & & \\
\hline Tidak Baik & 10 & 55,6 & 8 & 44,4 & $\begin{array}{l}0,02 \\
0\end{array}$ & 3,654 & $\begin{array}{l}1,189- \\
11,231\end{array}$ \\
\hline Baik & 13 & 25,5 & 38 & 74,5 & & & \\
\hline Jumlah & 23 & 33,3 & 46 & 66,7 & & & \\
\hline
\end{tabular}

Berdasarkan pada tabel 8 diketahui bahwa praktik pencegahan TB paru yang tidak baik sebagian besar terdapat kejadian TB paru (55,6\%) dan praktik pencegahan TB paru baik dan yang tidak menderita TB paru $(50,0 \%)$. Hasil uji Chi Square diperoleh $p$ value sebesar 0,020 yang lebih kecil dari $\alpha=0,05$ artinya ada hubungan antara praktik pencegahan TB paru dengan kejadian TB Paru di Wilayah Kerja Puskesmas II Sumpiuh Kabupaten Banyumas. Nilai OR sebesar 3,654 menunjukkan bahwa praktik pencegahan TB paru yang tidak baik berisiko terjadinya TB paru sebesar 3,654 dibandingkan yang praktik pencegahan TB parunya baik.

TABEL 9. HUBUNGAN KONDISI KEPADATAN HUNIAN RUMAH PENDERITA TB PARU DENGAN KEJADIAN TB PARU DI WILAYAH KERJA PUSKESMAS II SUMPIUH KABUPATEN BANYUMAS

\begin{tabular}{|c|c|c|c|c|c|c|c|c|}
\hline \multirow{3}{*}{$\begin{array}{l}\text { Kondisi } \\
\text { Kepadatan } \\
\text { Rumah }\end{array}$} & \multicolumn{4}{|c|}{ Kejadian TB Paru } & \multirow{3}{*}{$p$} & \multirow{3}{*}{ OR } & \multirow{3}{*}{ CI95\% } & \\
\hline & \multicolumn{2}{|c|}{$\begin{array}{ll}\mathrm{Ya} & \\
\mathrm{n} & \%\end{array}$} & \multicolumn{2}{|c|}{ Tidak } & & & & \\
\hline & $\mathrm{n}$ & $\%$ & $\mathrm{n}$ & $\%$ & & & & \\
\hline $\begin{array}{l}\text { Tidak } \\
\text { memenuhi } \\
\text { syarat }\end{array}$ & 7 & 87,5 & 1 & 11,5 & 0,001 & 19,688 & $\begin{array}{l}2,244 \\
172,699\end{array}$ & - \\
\hline $\begin{array}{l}\text { Memenuhi } \\
\text { syarat }\end{array}$ & 16 & 26,2 & 45 & 73,8 & & & & \\
\hline Jumlah & 23 & 33,3 & 46 & 66,7 & & & & \\
\hline
\end{tabular}

\begin{tabular}{|c|c|c|c|c|c|c|c|}
\hline \multirow{3}{*}{$\begin{array}{l}\text { Kondisi } \\
\text { Kepadatan } \\
\text { Rumah }\end{array}$} & \multicolumn{4}{|c|}{ Kejadian TB Paru } & \multirow{3}{*}{$p$} & \multirow{3}{*}{ OR } & \multirow{3}{*}{ CI95\% } \\
\hline & \multicolumn{2}{|c|}{ Ya } & \multicolumn{2}{|c|}{ Tidak } & & & \\
\hline & $\mathrm{n}$ & $\%$ & $\mathrm{n}$ & $\%$ & & & \\
\hline $\begin{array}{l}\text { Tidak } \\
\text { memenuhi } \\
\text { svarat }\end{array}$ & 7 & 87,5 & 1 & 11,5 & 0,001 & 19,688 & $\begin{array}{l}2,244 \\
172,699\end{array}$ \\
\hline
\end{tabular}




\begin{tabular}{|c|c|c|c|c|c|c|c|}
\hline \multirow{3}{*}{$\begin{array}{l}\text { Kondisi } \\
\text { Kepadatan } \\
\text { Rumah } \\
\end{array}$} & \multicolumn{4}{|c|}{ Kejadian TB Paru } & \multirow{3}{*}{$p$} & \multirow{3}{*}{ OR } & \multirow{3}{*}{ CI95\% } \\
\hline & \multicolumn{2}{|c|}{ Ya } & \multicolumn{2}{|c|}{ Tidak } & & & \\
\hline & $\mathrm{n}$ & $\%$ & $\mathrm{n}$ & $\%$ & & & \\
\hline $\begin{array}{l}\text { Memenuhi } \\
\text { syarat }\end{array}$ & 16 & 26,2 & 45 & 73,8 & & & \\
\hline Jumlah & 23 & 33,3 & 46 & 66,7 & & & \\
\hline
\end{tabular}

Berdasarkan pada tabel 4.13 diketahui bahwa orang yang tinggal di rumah dengan kondisi kepadatan hunian rumah tidak memenuhi syarat dan terdapat kejadian TB paru $(87,5 \%)$ dan yang tidak memenuhi syarat sebagian besar terdapat kejadian TB paru (73,8\%). Hasil uji Chi Square diperoleh $p$ value sebesar 0,001 yang lebih kecil dari $\alpha=$ 0,05 artinya ada hubungan antara kondisi kepadatan hunian rumah dengan kejadian TB Paru di Wilayah Kerja Puskesmas II Sumpiuh Kabupaten Banyumas. Nilai OR sebesar 19,688 menunjukkan bahwa orang yang tinggal di rumah dengan kondisi kepadatan hunian rumah tidak memenuhi syarat berisiko terjadinya TB paru sebesar 19,688 dibandingkan yang tinggal di rumah dengan kondisi kepadatan hunian rumah yang memenuhi syarat.

Dari responden yang diteliti sebanyak 69 orang, yang praktik pencegahan TB paru tidak baik sebanyak 18 orang $(26,1 \%)$ dan yang baik sebanyak 51 orang (73,9\%).

Dari responden yang diteliti sebanyak 69 rumah, yang jenis lantai rumah tidak memenuhi syarat sebanyak 26 rumah (37,7\%) dan yang memenuhi syarat sebanyak 43 rumah $(62,3 \%)$.

Dari responden yang diteliti sebanyak 69 rumah, yang kondisi dinding rumah tidak memenuhi syarat sebanyak 14 rumah (20,3\%) dan yang memenuhi syarat sebanyak 55 rumah (79,7\%).

Responden yang diteliti sebanyak 69 rumah, yang ventilasi rumah tidak memenuhi syarat sebanyak 23 rumah (33,3\%) dan yang memenuhi syarat sebanyak 46 rumah (66,7\%). Responden yang diteliti sebanyak 69 rumah, yang kondisi dapur rumah tidak memenuhi syarat sebanyak 14 rumah (20,3\%) dan yang memenuhi syarat sebanyak 55 rumah $(79,7 \%)$. Responden yang diteliti sebanyak 69 rumah, yang kepadatan hunian tidak memenuhi syarat sebanyak 8 rumah $(11,6 \%)$ dan yang memenuhi syarat sebanyak 61 rumah $(88,4 \%)$.
Responden yang diteliti sebanyak 69 orang, diketahui sebanyak 23 orang menderita TB paru (33,3\%) dan sebanyak yang tidak menderita TB paru sebanyak 46 orang (66,7\%).

Berdasarkan pada tabel 8 diketahui bahwa praktik pencegahan TB paru yang tidak baik sebagian besar terdapat kejadian TB paru (55,6\%) dan praktik pencegahan TB paru baik dan yang tidak menderita TB paru $(50,0 \%)$. Hasil uji Chi Square diperoleh $p$ value sebesar 0,020 yang lebih kecil dari $\alpha=0,05$ artinya ada hubungan antara praktik pencegahan TB paru dengan kejadian TB Paru di Wilayah Kerja Puskesmas II Sumpiuh Kabupaten Banyumas. Nilai OR sebesar 3,654 menunjukkan bahwa praktik pencegahan TB paru yang tidak baik berisiko terjadinya TB paru sebesar 3,654 dibandingkan yang praktik pencegahan TB parunya baik.

Berdasarkan pada tabel 9 diketahui bahwa orang yang tinggal di rumah dengan kondisi kepadatan hunian rumah tidak memenuhi syarat dan terdapat kejadian TB paru $(87,5 \%)$ dan yang tidak memenuhi syarat sebagian besar terdapat kejadian TB paru (73,8\%). Hasil uji Chi Square diperoleh $p$ value sebesar 0,001 yang lebih kecil dari $\alpha=$ 0,05 artinya ada hubungan antara kondisi kepadatan hunian rumah dengan kejadian TB Paru di Wilayah Kerja Puskesmas II Sumpiuh Kabupaten Banyumas. Nilai OR sebesar 19,688 menunjukkan bahwa orang yang tinggal di rumah dengan kondisi kepadatan hunian rumah tidak memenuhi syarat berisiko terjadinya TB paru sebesar 19,688 dibandingkan yang tinggal di rumah dengan kondisi kepadatan hunian rumah yang memenuhi syarat.

\section{KESIMPULAN DAN SARAN}

\section{A. Kesimpulan}


Berdasarkan uraian pada hasil penelitian dan pembahasan dapat diambil kesimpulan sebagai berikut :

1. Praktik pencegahan TB paru tidak baik sebanyak 18 orang $(26,1 \%)$ dan yang baik sebanyak 51 orang $(73,9 \%)$.

2. Jenis lantai rumah tidak memenuhi syarat sebanyak 26 rumah (37,7\%) dan yang memenuhi syarat sebanyak 43 rumah (62,3\%). Kondisi dinding rumah tidak memenuhi syarat sebanyak 14 rumah $(20,3 \%)$ dan yang memenuhi syarat sebanyak 55 rumah (79,7\%). Ventilasi rumah tidak memenuhi syarat sebanyak 23 rumah $(33,3 \%)$ dan yang memenuhi syarat sebanyak 46 rumah (66,7\%). Kondisi dapur rumah tidak memenuhi syarat sebanyak 14 rumah (20,3\%) dan yang memenuhi syarat sebanyak 55 rumah (79,7\%). Kepadatan hunian tidak memenuhi syarat sebanyak 8 rumah $(11,6 \%)$ dan yang memenuhi syarat sebanyak 61 rumah $(88,4 \%)$

3. Ada hubungan antara praktik pencegahan TB paru dengan kejadian TB Paru di Wilayah Kerja Puskesmas II Sumpiuh Kabupaten Banyumas ( $p$ value $=0,020$ ). Nilai OR sebesar 3,654 menunjukkan bahwa praktik pencegahan TB paru yang tidak baik berisiko terjadinya TB paru sebesar 3,654 dibandingkan yang praktik pencegahan TB parunya baik.

4. Ada hubungan antara jenis lantai dengan kejadian TB Paru di Wilayah Kerja Puskesmas II Sumpiuh Kabupaten Banyumas ( $\mathrm{p}$ value $=0,022)$. Nilai OR sebesar 3,300 menunjukkan bahwa orang yang tinggal di rumah dengan jenis lantai tidak memenuhi syarat berisiko terjadinya TB paru sebesar 3,300 dibandingkan yang tinggal di rumah dengan jenis lantai yang memenuhi syarat.

5. Ada hubungan antara dinding rumah dengan kejadian TB Paru di Wilayah Kerja Puskesmas II Sumpiuh Kabupaten Banyumas ( $\mathrm{p}$ value $=0,001)$. Nilai OR sebesar 6,395 menunjukkan bahwa orang yang tinggal di rumah dengan dinding rumah tidak memenuhi syarat berisiko terjadinya TB paru sebesar 6,395 dibandingkan yang tinggal di rumah dengan dinding rumah yang memenuhi syarat.
6. Ada hubungan antara ventilasi rumah dengan kejadian TB Paru di Wilayah Kerja Puskesmas II Sumpiuh Kabupaten Banyumas ( $\mathrm{p}$ value $=0,019$ ). Nilai OR sebesar 3,471 menunjukkan bahwa orang yang tinggal di rumah dengan ventilasi rumah tidak memenuhi syarat berisiko terjadinya TB paru sebesar 3,471 dibandingkan yang tinggal di rumah dengan ventilasi rumah yang memenuhi syarat.

7. Ada hubungan antara kondisi fisik dapur dengan kejadian TB Paru di Wilayah Kerja Puskesmas II Sumpiuh Kabupaten Banyumas ( $\mathrm{p}$ value $=0,006$ ). Nilai $\mathrm{OR}$ sebesar 5,271 menunjukkan bahwa orang yang tinggal di rumah dengan ventilasi rumah tidak memenuhi syarat berisiko terjadinya TB paru sebesar 5,271 dibandingkan yang tinggal di rumah dengan kondisi fisik dapur yang memenuhi syarat.

8. Ada hubungan antara kondisi kepadatan hunian rumah dengan kejadian TB Paru di Wilayah Kerja Puskesmas II Sumpiuh Kabupaten Banyumas ( $\mathrm{p}$ value $=0,001$. Nilai OR sebesar 19,688 menunjukkan bahwa orang yang tinggal di rumah dengan kondisi kepadatan hunian rumah tidak memenuhi syarat berisiko terjadinya TB paru sebesar 19,688 dibandingkan yang tinggal di rumah dengan kondisi kepadatan hunian rumah yang memenuhi syarat.

\section{B. Saran}

Berdasarkan pada hasil penelitian tersebut di atas, dapat diberikan saran-saran sebagai berikut:

1. Bagi Institusi Pendidikan

Hasil penelitian ini perlu dipublikasikan sebagai bahan referensi ilmiah dan kepustakaan sekaligus sebagai bahan pengembangan ilmu kesehatan khususnya penanggulangan penyakit TB paru di masyarakat melalui perubahan perilaku dan perbaikan lingkungan.

2. Bagi Institusi Kesehatan

Penelitian ini diharapkan dapat menjadi bahan masukan dalam menjalankan program penanggulangan penyakit TB Paru, melalui perubahan perilaku dan perbaikan lingkungan. 


\section{Bagi Peneliti}

Penelitian ini perlu dikembangkan lebih lanjut dengan meneliti faktor lain yang dapat mempengaruhi kejadian TB paru dari aspek sosial ekonomi masyarakat, seperti pendidikan, pekerjaan dan jenis kelamin.

\section{Daftar Pustaka}

Arikunto, S. 2006. Prosedur Penelitian Suatu Pendekatan Praktik. Jakarta: Rineka Cipta.

Budiarto, Eko 2004. Metode Penelitian. Jakarta: EGC

Chin, James. 2000, Manual Pemberantasan Penyakit

Menular, Jakarta.Infomedika.

Dahlan, Sopiyudin M, 2008. LangkahLangkah Membuat Proposal Penelitian Bidang. Kedokteran dan Kesehatan. Jakarta : Sagung Seto.

Depkes, RI. 2006. Pedoman Nasional Penanggulangan Tuberkulosis. Jakarta: Depkes RI.

Depkes RI, 2008. Pedoman Nasional Penanggulangan Tuberkulosis. Jakarta: Depkes RI

Dinkes Jateng, 2013. Profil Kesehatan Provinsi Jawa Tengah 2013. Semarang: Dinkes Jateng.

Entjang Indan, 2000. Ilmu Kesehatan Masyarakat. Bandung..Citra Aditya Bakti.

Erika, Untari Dewi. 2012 Pengaruh Pengawas Menelan Obat (PMO) terhadap Kepatu-han Minum Obat Pada Pasien Tuberkulosis (TB) di Puskesmas Kedurus Surabaya. http://ejournal.akperwilliambooth.ac.i d/index.php/D3KEP/issue/current/sho wToc
Erwin Ulinnuha Fahreza, 2012. Hubungan antara Kualitas Fisik Rumah dan Kejadian Tuberkulosis Paru dengan Basil Tahan Asam Positif di Balai Kesehatan Paru Masyarakat Semarang, Jurnal Kedokteran Muhammadiyah, Vol. 1, No. 1, 9-13,

Fahdhienie, Farah. 2011. Case Distribution of Pulmonary Tuberculosis and Risk Factor in Gunung Kidul, Tesis, Graduate Program Medical Faculty Gadjah Mada University, Yokyakarta, Universitas Gajah Mada,

Fatimah, Siti. 2008. Faktor Kesehatan Lingkungan Rumah yang Berhubungan dengan Kejadian TB Paru di Kabupaten Cilacap (Kecamatan: Sidareja, Cipari, Kedungreja, Patimuan, Gandrumangu, Bantarsari) Tahun 2008, Tesis, Semarang, Universitas Diponegoro,

Guyton, A. C., 2008. Buku Ajar-Fisiologi Kedokteran Jakarta: EGC.

Imam, Bachtiar, 2008. Hubungan Perilaku dan kondisi Lingkungan Fisik Rumah dengan Kejadian TB Paru di Kota Bima Provinsi NTB.

http://repository.unhas.ac.id/han dle/123456789/3935

Kasamssi. P.2010. Hubungan antara luas ventilasi dan pencahayaan rumah dengan kejadian tuberculosis paru anak di wilayah kerja puskesmas Kedungmundu Kecamatan Tembalang Semarang tahun 2010. Jurnal kesehatan masyarakat volume 3/ no 2.

Kemenkes RI, 2011. Terobosan Menuju Akses Universal Strategi Nasional Pengendalian Tb Di Indonesia 20102014.

http://www.searo.who.int/indonesia/to pics/tb/stranas_tb-2010-2014.pdf 
Kemenkes RI, 2013. Profil Kesehatan Indonesia Tahun 2013. Jakarta: Kemenkes RI.

Kemenkes RI, 2015. Pelaksanaan Hari TB Sedunia 2015 Di Provinsi Bali Selasa, $24 \quad$ Maret 2015. http://www.diskes.baliprov.go.id/id/pe laksanaan-hari-tb-sedunia-2015-diprovinsi-bali-selasa--24-maret-20152

Lumban T. Tobing, 2008. Pengaruh Penderita TB Paru dan Kondisi Rumah terhadap Pencegahan Potensi Penularan TB Paru pada Keluarga di Kabupaten Tapanuli Utara Tahun 2008, Tesis, Medan, Program Pascasarjana Universitas Sumatera Utara,

Lusy Ika Susanti. 2016. Hubungan Antara Kondisi Fisik Rumah Dan Perilaku Dengan Kejadian Tuberkulosis Paru Di Wilayah Kerja Puskesmas Sangkrah Kota Surakarta Tahun 2016.

http://eprints.ums.ac.id/44147/2/HAL

AMAN\%20DEPAN.pdf

Mansur, A, 2007. Kapita Selekta Kedokteran. Jakarta. Media Aesculapius FKUI.

Murray, M, Modelling social, environmental and biological determinants of tuberculosis, Boston, International Journal Tuberculosis and Lung Disease, 15(6): 64-70, 2011

Murtiningsih, Dwi Ary 2014. Pengaruh Luas Ventilasi terhadap Kejadian TB Paru di Wilayah Kerja Puskesmas Sukoharjo Kabupaten Sukoharjo Tahun 2013.

http://eprints.ums.ac.id/30993/10/11._ naskah_publikasi.pdf

Notoatmodjo, S. 2007. Metodologi Penelitian Kesehatan. Jakarta: Rineka Cipta

Price and Wilson. 2005. Konsep Klinis Proses-Proses Penyakit. Jakarta : EGC.
Refinia. Anastasya Saharieng 2013 Faktorfaktor yang Berhubung-an de-ngan Status Kesembuhan Pasien Tuberkulosis Paru di Wilayah Kerja Puskesmas Tamako, Puskesmas Manganitu dan Puskesmas Tahuna Timur di Kabupaten Kepulauan Sangihe. http://fkm.unsrat.ac.id/wpcontent/uploads/2014/11/ArtikelTasya-saharieng.pdf

Riyanti, Syarif. 2011. mekanisme penularan tuberkulosis(online) http://keperawatanku.blogspot.com/20 10/08/kewaspadaan-universaluniversal.html

Rosiana Anggie Mareta. 2013. Hubungan Antara Kondisi Fisik Rumah Dengan Kejadian Tuberkulosis Paru. Unnes Journal of Public Health UJPH 2 (1)

Ryana Ayu Setia Kurniasari. 2012. Faktor Risiko Kejadian Tuberkulosis Paru di Kecamatan Baturetno Kabupaten Wonogiri. Media Kesehatan Masyarakat Indonesia, Vol.11/No.2, Oktober 2012

Setiawan Dwi Antoro. 2012 Hubungan Faktor Lingkungan Fisik Rumah dan Respons Terhadap Praktik Pengobatan Strategi DOTS Dengan Penyakit Tb Paru di Kecamatan Tirto Kabupaten Pekalongan Tahun 2010. Jurnal Kesehatan Lingkungan Indonesia Vol. 11 No. 1 / April 2012

Suharjana B., Kristiana, 2005, Pelaksanaan Penemuan Penderita Tuberkulosis di Puskesmas Kabupaten Sleman, Yogyakarta, KMPK UGM.

Suharyono. 2008. Diare akut Klinik dan Laboratorik. Rhineka Cipta. Jakarta.

Suliha, Uha, 2002. Pendidikan Kesehatan : Pendidikan Kesehatan, Jakarta, EGC.

Umar Fahmi Achmadi, 2008. Manajemen Penyakit Berbasis Wilayah, Jakarta, UIPress, 